\title{
Old Habits Die Hard: The Textbook Presidency Is Alive and Well
}

\author{
J. M. Sanchez, Adelphi University
}

In their treatments of the presidency, American Government textbooks routinely provide direct evaluations of the 40 individuals who have held the office. Although introductory textbooks represent a huge portion of the books published on American politics, they have been mostly ignored as sources of data on presidential evaluations. The few scholarly analyses of the approaches followed by the authors of texts have focused on depictions of the presidential institution, rather than on assessments of the individuals who have occupied the White House.

In reviewing $\mathbf{4 0}$ books on American government published during the past seven years, I have focused exclusively on comments directly evaluating individual chief executives. ${ }^{1}$ All mentions of a president were catalogued according to the judgment expressed by the author, and the findings are summarized in the tables appearing below.

The total numbers reveal an overwhelmingly negative appraisal of the 41 men who have worked in the Oval Office. Of 5,882 evaluative references to specific presidents, only 2,265 are positive, a paltry approval rate of $38.5 \% .^{2}$ The numbers are even more discouraging when only modern presidents are judged. Of 4,465 comments about the post-World War II presidents, only $33 \%(1,463)$ are favorable. In short, readers of these books are left with the unmistakable impression that the American presidency has been in the hands of largely inept public officials.

As one may anticipate in political science texts, most of the examples cited by the authors are drawn from recent presidents (see Table One). Presidents that I assigned to Group One (Franklin Roosevelt through Bill Clinton) account for a whopping $82 \%$ of all referencesnearly one half of the evaluative statements are addressed to the three most often mentioned presidents (Ronald Reagan, Richard

\begin{tabular}{|c|c|c|}
\hline & $\begin{array}{l}\text { BLE ONE } \\
\text { sidents Ranked Accordin } \\
\text { quency of Comments }\end{array}$ & \\
\hline & GROUP ONE & \\
\hline 1 & Ronald Reagan - & 1307 \\
\hline 2 & Richard Nixon & 823 \\
\hline 3 & Jimmy Carter & 626 \\
\hline 4 & George Bush & 414 \\
\hline 5 & Lyndon Johnson & 401 \\
\hline 6 & Franklin Roosevelt & 349 \\
\hline 7 & John Kennedy & 332 \\
\hline 8 & Dwight Eisenhower & 205 \\
\hline 9 & Gerald Ford & 137 \\
\hline 10 & Harry Truman & 135 \\
\hline 11 & Bill Clinton & 85 \\
\hline & GROUP TWO & \\
\hline 1 & George Washington & 140 \\
\hline 2 & Woodrow Wilson_ & 126 \\
\hline 3 & Thomas Jefferson_- & 105 \\
\hline 4 & Abraham Lincoln & 94 \\
\hline 5 & Andrew Jackson & 82 \\
\hline 6 & Theodore Roosevelt _ & 79 \\
\hline 7 & James Madison & 75 \\
\hline & GROUP THREE & \\
\hline 1 & Andrew Johnson & 55 \\
\hline 2 & Warren Harding _ & 39 \\
\hline 3 & Herbert Hoover & 35 \\
\hline 4 & John Adams & 28 \\
\hline & James Garfield _ & 28 \\
\hline 6 & Ulysses Grant & 18 \\
\hline & James Polk & 18 \\
\hline 8 & Grover Cleveland & 16 \\
\hline & Calvin Coolidge & 16 \\
\hline & John Tyler & 16 \\
\hline 11 & William McKinley - & 15 \\
\hline 12 & Rutherford Hayes & 14 \\
\hline 13 & John Quincy Adams & 12 \\
\hline 14 & Benjamin Harrison & 11 \\
\hline 15 & William H. Harrison & 9 \\
\hline & James Monroe & 9 \\
\hline & Martin Van Buren & 9 \\
\hline 18 & William H. Taft_ & 8 \\
\hline 19 & Chester Arthur - & 6 \\
\hline 20 & James Buchanan & 5 \\
\hline 21 & Franklin Pierce & 4 \\
\hline & Zachary Taylor & 4 \\
\hline 23 & Millard Fillmore & 2 \\
\hline
\end{tabular}

Nixon, and Jimmy Carter). Since most modern presidents are roundly criticized, this preponderance of contemporary references contributes to the distressingly low overall statistics (see Table Two).

Group Two is comprised of those historical figures generally assigned to the pantheon of presidential greatness (see Table Three). The average rating here is $65 \%$, and it would be substantially higher (73\%) without Woodrow Wilson, the only president in Group Two with resounding negatives. Although Wilson is routinely assigned "great" or "near great" status in polls by historians and political scientists, he is excoriated in the American government texts for his inability to secure Senate ratification of the Treaty of Versailles.

James Madison is another name in Group Two which requires clarification. Madison heads the list with a rating of $83 \%$ even though presidential experts have never listed him higher than "average." Practically all of the accolades that the texts heap on Madison refer not to his presidency, but to his role at the 1787 Constitutional Convention as well as to his contributions to The Federalist Papers. ${ }^{3}$

The remaining 23 presidents are listed in Group Three (see Table Four). Men with relatively obscure reputations and modest accomplishments, these individuals are seldom remembered in the texts. As with recent presidents, those in Group Three who are strongly rebuked for their performances are mentioned with more frequency than the others: Andrew Johnson (the only president ever impeached), Warren Harding (with the most corrupt administration in history), and Herbert Hoover (still associated with the Great Depression).

One oddity among the Group Three presidents is the perfect rating for James Garfield, the second president to be assassinated. ${ }^{4}$ The 28 references to his death practically proclaim Garfield a martyr whose death opened the way for the creation of the federal civil service system. The least mentioned chief executive is Millard Fillmore; cited only twice, Fillmore remains "the unknown president."'s

In the most extensive analysis of how textbooks treat the presidency, Thomas Cronin concluded that the picture of the president which emerged from the texts was highly unrealistic. ${ }^{6}$ Writing more 


\begin{tabular}{|c|c|c|c|c|}
\hline & & $\begin{array}{c}\text { Total } \\
\text { References }\end{array}$ & $\begin{array}{c}\text { Positive } \\
\text { References }\end{array}$ & Percentage \\
\hline 1 & F. Roosevelt & 349 & 230 & 66 \\
\hline 2 & D. Eisenhower & 205 & 130 & 63 \\
\hline 3 & J. Kennedy & 332 & 204 & 61 \\
\hline 4 & L. Johnson & 401 & 206 & 51 \\
\hline 5 & B. Clinton & 85 & 32 & 38 \\
\hline 6 & G. Bush & 414 & 154 & 37 \\
\hline 7 & H. Truman & 135 & 50 & 37 \\
\hline 8 & R. Reagan & 1307 & 416 & 32 \\
\hline 9 & G. Ford & 137 & 35 & 26 \\
\hline 10 & J. Carter & 626 & 139 & 22 \\
\hline \multirow[t]{2}{*}{11} & R. Nixon & 823 & 97 & 12 \\
\hline & Total & 4814 & 1693 & 35 \\
\hline
\end{tabular}

\section{TABLE THREE}

Evaluative References to Presidents in Group Two

\begin{tabular}{llccc}
\hline & $\begin{array}{c}\text { Total } \\
\text { References }\end{array}$ & $\begin{array}{c}\text { Positive } \\
\text { References }\end{array}$ & Percentage \\
\hline 1 & J. Madison & 75 & 62 & 83 \\
2 & G. Washington & 140 & 104 & 74 \\
3 & T. Roosevelt & 79 & 58 & 73 \\
4 & A. Jackson & 82 & 60 & 73 \\
5 & T. Jefferson & 105 & 71 & 68 \\
6 & A. Lincoln & 94 & 62 & 66 \\
7 & W. Wilson & 126 & 37 & 29 \\
& Total & 701 & 454 & 65 \\
\hline
\end{tabular}

than 20 years ago, Cronin noted that "textbook presidents" were deemed far more powerful than the actual officeholders. A subsequent revision of Cronin's data by Douglas J. Hoekstra demonstrated that textbooks were still creating unrealistic expectations of the president by listing the many "roles" which he was expected to play. ${ }^{7}$ By anticipating presidents to fulfill such an ambitious assortment of duties, the texts were condemning them to inescapable failure.

My findings support the thesis that textbooks are continuing to grade presidential performance according to unreasonable standards. Most books still furnish students with an imposing checklist of roles. To cite a typical example, a 1995 text offers the following eight "roles": Chief of State, Chief Diplomat, Commander-in-Chief, Chief Administrator, Chief Legislator, Party Leader, National Opinion Leader, and Manager of the Economy. ${ }^{8}$ With " powers" allegedly attached to these roles, the books create the image of a dominating officeholder who towers over the entire political system. When measuring the effectiveness of modern presidents against such inflated pre- scriptions, it is hardly surprising that very few individuals emerge with favorable notices.

Paradoxically, these extensive lists of titles and powers have not yielded a uniform method of gauging presidential greatness. Readers are simply told that Washington and Lincoln were among the very best presidents, but little substantive information is offered to validate their lofty status. Historical events are rattled off as successes or failures without any amplifying analysis of the situation to highlight the president's involvement and the options that he considered implementing before reaching a final judgment.

Of those in Group One who have positive evaluations (Franklin Roosevelt, Dwight Eisenhower, and John Kennedy), only the references to FDR's years in office include specific accomplishments. Both Eisenhower and Kennedy earn high marks for the personal impact that their charisma made on the office, but textbook authors do not seem willing to accept Eisenhower's "hidden hand" leadership style. Pardoxically, Eisenhower is taken to task for his lukewarm support of civil rights at the same time
TABLE FOUR

Evaluative References to Presidents in Group Three

\begin{tabular}{|c|c|c|c|c|}
\hline & & $\begin{array}{c}\text { Total } \\
\text { References } \\
\end{array}$ & $\begin{array}{c}\text { Positive } \\
\text { References } \\
\end{array}$ & Percentage \\
\hline 1 & J. Garfield & 28 & 28 & 100 \\
\hline 2 & J. Monroe & 9 & 7 & 78 \\
\hline 3 & W. McKinley & 15 & 11 & 73 \\
\hline 4 & C. Arthur & 6 & 4 & 67 \\
\hline 5 & G. Cleveland & 16 & 10 & 62 \\
\hline 6 & W. H. Harrison & 9 & 5 & 56 \\
\hline \multirow[t]{2}{*}{7} & J. Tyler & 16 & 8 & 50 \\
\hline & Z. Taylor & 4 & 2 & 50 \\
\hline 9 & J. Polk & 18 & 7 & 39 \\
\hline 10 & M. Van Buren & 9 & 3 & 33 \\
\hline 11 & C. Coolidge & 16 & 3 & 19 \\
\hline 12 & A. Johnson & 55 & 10 & 18 \\
\hline 13 & J. Q. Adams & 12 & 2 & 17 \\
\hline \multirow[t]{3}{*}{14} & J. Adams & 28 & 4 & 14 \\
\hline & H. Hoover & 35 & 5 & 14 \\
\hline & R. Hayes & 14 & 2 & 14 \\
\hline 17 & U. Grant & 18 & 2 & 11 \\
\hline 18 & W. Harding & 39 & 4 & 10 \\
\hline 19 & B. Harrison & 11 & 1 & 9 \\
\hline 20 & M. Fillmore & 2 & 0 & 0 \\
\hline 21 & F. Pierce & 4 & 0 & 0 \\
\hline 22 & J. Buchanan & 5 & 0 & 0 \\
\hline \multirow[t]{2}{*}{23} & W. H. Taft & 8 & 0 & 0 \\
\hline & Total & 367 & 118 & 32 \\
\hline
\end{tabular}


that he is praised for his enforcement of the Brown decision in Little Rock. As for Kennedy, the aura of Camelot has proved remarkably resilient in light of his meager record of actual attainments. There are still more descriptions of Kennedy's youth and perceived enthusiasm than of concrete policy initiatives.

The critical slings and arrows are particularly sharp when dealing with the most recent presidents. Few mistakes, gaffes, or oversights go unnoticed. Ronald Reagan, the only president in the last 40 years to have served two full terms, is mentioned more than 1,300 times, and fewer than one-third of those allusions are commendatory. Such ranking places Reagan eighth among the last 11 chief executives, ahead only of Gerald Ford (an accidental president), Jimmy Carter (the man Reagan defeated in 1980), and Richard Nixon (an unindicted felonious co-conspirator) ${ }^{9}$

Contemporary presidents are also handicapped by the relative disregard that most texts show for foreign policy. Some books include a brief discussion of international politics only under the president's roles as "chief diplomat" and "commander-in-chief," while texts that devote an entire chapter to foreign policy normally relegate it to the end of the book. The termination of the Cold War has further encouraged the public as well as textbook authors to focus on domestic concerns. Since even presidents with extensive domestic agendas (Lyndon Johnson and Bill Clinton, for example) may be judged by their handling of inherited international crises, a general neglect of foreign policy would seem to lower appraisals of a president's effectiveness.

Finally, most authors of introductory textbooks have adopted a "bottom line" approach to policy evaluation. If a presidential initiative does not garner Congressional support, it is automatically pronounced a failure. This approach understates the importance of a legislatively innovative president who deserves credit for forcing the system to address a particular issue theretofore neglected. For example, texts are already describing the Clinton administration's health care proposal as a "failure" because it was not approved by Congress; lost in these postmortem dissections of the White House strategy is the fact that Clinton was the first president to place national health on the public policy agenda.

In conclusion, undergraduate students relying on these introductory texts will be given the impression that most of the men who worked in the Oval Office have fallen far short of the competence level expected by scholars in the field. While the books reserve the specific term "failure" only for the likes of Warren Harding, Ulysses Grant, or Andrew Johnson, their remarks about contemporary presidents are not encouraging. In fact, the negatives of Nixon, Ford, Carter, Reagan, and Bush outweigh their positives by a four to one ratio. Nothing in the early returns suggests that Bill Clinton (38\%) will break this disturbing pattern.

With negative advertising, term limits, and the strong anti-government undercurrent of the "Contract With America," there seems to be a widespread feeling that the American political system, at least at the federal level, is no longer functioning as it was designed to do. The anger and cynicism expressed by the electorate in its 1994 rejection of "government as usual" certainly is not assuaged by the information contained in these texts. In fact, their calamitous assessments may be creating a new American political myth: trusting voters are being let down by untalented national leaders. Or as Ellis and Wildavsky put it: "The historical reading of America as a land particularly favored by providence," may be replaced with a portrait of Americans "as an unlucky people done in by unworthy presidents." 10

\section{Notes}

1. The $\mathbf{4 0}$ books are listed below. They represent a broad cross-section of introductory American government texts published between 1989 and 1996

2. I categorized as "evaluative" references, remarks which clearly indicated a positive or negative conclusion about the president in question.

3. Madison's case illustrates one of the methodological problems associated with a project of this nature. I have included references to a president's activities prior to service in the White House under the assumption that undergraduate students, the primary audience for these texts, would be less likely to independently distinguish an individual's historical contributions from his record as president. To some extent, the ratings of George Washington and Thomas Jefferson are also inflated by the plaudits they earn for activities that preceded their elections to the presidency.

4. Oddly, only six books point out that one of the "greats," Lincoln, was the first of four presidents to be murdered.

5. Beson Lee Grayson, The Unknown President: The Administration of Millard Fillmore. University Press of America (Washington), 1981.

6. Thomas Cronin "The Textbook Presidency and Political Science." Stanley Bach and George T. Sulzner (eds.) Perspectives on the Presidency. D.C. Heath (Lexington, MA), 1974.

7. Douglas J. Hoesktra, "The 'Textbook Presidency' Revisited." Presidential Studies Quarterly, vol. 12 (Winter 1982).

8. Walter E. Volkomer, American Government (7th ed.). Prentice Hall, (Englewood Cliffs, NJ) 1995, pp. 195-210.

9. The rehabilitative efforts of some presidential scholars notwithstanding, the reputations of Carter and Nixon have yet to be revised.

10. Richard Ellis and Aaron Wildavsky. " "Greatness' Revisited: Evaluating the Performance of Early American Presidents in Terms of Cultural Dilemmas." Presidential Studies Quarterly, vol. 21 (Winter 1991), pp. 31-32.

\section{Textbooks Reviewed}

Bardes, Barbara A., Mack C. Shelley II, and Steffen W. Schmidt. 1990. American Government and Politics Today: The Essentials, 3rd ed. St. Paul, MN: West.

Barilleaux, Ryan J. 1996. American Government in Action: Principle, Process and Politics. Upper Saddle River, NJ: Prentice-Hall.

Burns, James MacGregor, J. W. Peltason, and Thomas E. Cronin. 1990. Government by the People, 14th ed. Englewood Cliffs, NJ: Prentice Hall.

Cummings, Milton C., and David Wise. 1989. Democracy Under Pressure: An Introduction to the American Political System, 6th ed. San Diego: Harcourt, Brace, Jovanovich.

Dye, Thomas R., and Harmon Zeigler. 1989. American Politics in the Media Age, 3rd ed. Pacific Grove, CA: Brooks/Cole.

Flammang, Janet A., Dennis R. Gordon, Timothy J. Lukes, and Kenneth R. Smortsen. 1990. American Politics in A Changing World. Pacific Grove, CA: Brooks/Cole.

Gitelson, Alan R., Robert L. Dudley, and 
Melvin J. Dubnick. 1991. American Government, 2nd ed. Boston: Houghton Mifflin.

Greenberg, Edward S. 1989. The American Political System: A Radical Approach, 5th ed. Glenview, IL: Scott, Foresman.

Greenberg, Edward S., and Benjamin I. Page. 1993. The Struggle For Democracy. New York: HarperCollins.

Havick, John. 1991. American Democracy in Transition: A Communications Revolution. St. Paul, MN: West.

Holmes, Jack E., Michael J. Engelhardt, and Robert E. Elder. 1991. American Government: Essentials and Perspectives. New York: McGraw Hill.

Janda, Kenneth, Jeffrey M. Berry, Jerry Goldman, and Earl Huff. 1990. The Challenge of Democracy: Government in America (brief edition). Boston: Houghton Mifflin.

Janda, Kenneth, et al. 1989. The Challenge of Democracy: Government in America, 2nd ed. Boston: Houghton Mifflin.

Keefe, William J., Henry J. Abraham, William H. Flanigan, Charles O. Jones, Morris S. Ogul, and John W. Spanier. 1990. American Democracy: Institutions, Politics, and Policies (3rd Edition). New York: Harper \& Row.

Ladd, Everett Carll. 1991. The American Polity: The People and Their Government, 4th ed. New York: W.W. Norton.

Le Loup, Lance T. 1991. Politics in America: The Ability to Govern (3rd ed.). St. Paul, MN: West.

Lineberry, Robert L., George C. Edwards III, and Martin P. Wattenberg. 1991. Government in America: People, Politics, and Policy, 5th ed. New York: Harper-Collins.

Lipsitz, Lewis, and David M. Speak. 1989. American Democracy, 2nd ed. New York: St. Martin's.

Lowi, Theodore J., and Benjamin Ginsberg.
1990. American Government: Freedom and Power. New York: W.W. Norton.

Lyons, William, Johgn M. Scheb II, and Lilliard E. Richardson, Jr. 1995. American Government: Politics and Political Culture. Minneapolis: West.

McKenna, George. 1990. The Drama of Democracy: American Government and Politics. Guilford, CT: Dushkin.

Moore, Jr., John A., and Myron Roberts. 1989. The Pursuit of Happiness: Government and Politics in America, 4th ed. New York: Macmillan.

O'Connor, Karen, and Larry J. Sabato. 1996. American Government: Roots and Reform, 2nd ed. Boston: Allyn and Bacon.

O'Connor, Robert E., Thomas G. Ingersoll, and Robert F. Pecorella. 1990. Politics and Structure: Essentials of American National Government, Sth ed. Pacific Grove, CA: Brooks/Cole.

Patterson, Samuel, Roger H. Davidson, and Randall B. Ripley. 1989. A More Perfect Union: Introduction to American Government, 4th ed. Pacific Grove, CA: Brooks/Cole.

Patterson, Thomas E. 1990. The American Democracy. New York: McGraw-Hill.

Prewitt, Kenneth, Sidney Verba, and Robert H. Salisbury. 1991. An Introduction to American Government, 6th ed. New York: HarperCollins.

Reynolds, H. T., and David Vogler. 1991. Governing America. New York: HarperCollins.

Ross, Robert S. 1991. American National Government: Institutions, Policy and Participation, 2nd ed. Guilford, CT: Dushkin.

Saffell, David C. 1989. Essentials of American Government: Change and Continuity. Pacific Grove, CA: Brooks/Cole.

Saye, Albert B., and John F. Allums. 1990. Principles of American Government, 11th ed. Englewood Cliffs, NJ: Prentice-Hall.
Sherrill, Robert. 1990. Why They Call It Politics: A Guide to America's Government, 5th ed. San Diego: Harcourt Brace Jovanovich.

Stone, Alan, and Richard P. Barke. 1990. Governing the American Republic: Economics, Law and Policies, 2nd ed. New York: St. Martin's.

Tannahill, Neal, and Wendell M. Bedichek. 1991. American Government: Policy and Politics, 3rd ed. New York: HarperCollins.

Volkomer, Walter E. 1995. American Government, 7th ed. Englewood Cliffs, NJ: Prentice Hall.

Wasserman, Gary. 1991. The Basics of American Politics, 6th ed. New York: HarperCollins.

Welch, Susan, John Gruhl, Michael Steinman, and John Comer. 1991. Understanding American Government. St. Paul, MN: West.

Wilson, James Q. 1990. American Government: Brief Version, 2nd ed. Lexington, MA: D.C. Heath

Wilson, James Q. 1992. American Government: Institutions and Policies, 5th ed. Lexington, MA: D.C. Heath.

Woll, Peter, and Robert H. Binstock. 1991. America's Political System: A Text with Cases. New York: McGraw-Hill.

Woll, Peter, and Sidney E. Zimmerman. 1989. American Government: The Core. New York: Random House.

\section{About the Author}

J. M. Sanchez is an associate professor of political science at Adelphi University. He has published articles on constitutional law and American political films. He is currently completing research on the activities of former presidents.

\title{
Local News, Presidential Campaigns, and Citizenship Education: A Reform Proposal
}

\author{
Robert N. Roberts and Anthony J. Eksterowicz, James Madison University
}

The 1992 presidential election campaign highlighted the ability of national campaigns to bypass experienced national political reporters. Both the Bush and Clinton campaigns used the latest technology to send their messages to local media markets across the country. Satellite hookups permitted campaign spin doctors to tailor their messages to local audiences and to interact with local news personalities. Equally important, the candi- dates participated more frequently in participatory news and talk programs. George Bush and Bill Clinton appeared on television talk shows like Larry King Live, The Phil Donahue Show, and radio call-in shows such as Immus In the Morning and Rush Limbaugh (Rideout 1993, 712).

Despite the excellent political coverage in many daily newspapers, the decline in newspaper readership makes citizens more de- pendent upon television and radio for political information (Robinson $1980,219)$. When politicians tailor political campaigns to local audiences, they heighten the role performed by local news people and talk-show mavens in interpreting the message sent to potential voters.

The ability of politicians to go over the heads of national and local media has raised serious questions regarding the media's ability to pro- 